\title{
Intensi Membeli, Jenis Kelamin, Gender Produk, dan Tujuan Konsumsi
}

\author{
Lerbin R. Aritonang R. dan Stefani \\ Fakultas Ekonomi dan Bisnis, Universitas Tarumanagara \\ Email: aritonanglerbin@gmail.com; Stefani@fe.untar.ac.id
}

\begin{abstract}
Abstrak: Penelitian ini dimaksudkan untuk menguji kaitan antara intensi konsumen untuk membeli produk dengan jenis kelamin, gender produk dan tujuan konsumsi. Subjek penelitian ini adalah 141 mahasiswa/i perguruan tinggi swasta di Jakarta. Intensi membeli diukur dengan skala Likert. Penelitian ini dilakukan dengan menggunakan desain deskriptif. Analisis yang digunakan adalah Anava (analisis variansi). Dari penelitian yang dilakukan diketahui bahwa intensi membeli produk berkaitan dengan jenis kelamin, warna dan bentuk produk, serta tujuan (manfaat) konsumsi. Peran tujuan konsumsi untuk memoderasi kaitan antara intensi membeli produk dan warna maupun bentuk produk tidak teruji secara empiris. Kontribusi penelitian ini berkaitan dengan penggunaan intensi membeli untuk dijelaskan melalui gender produk yang mungkin masih jarang diteliti.
\end{abstract}

Kata Kunci: intensi membeli, jenis kelamin, gender produk dan tujuan konsumsi.

\section{PENDAHULUAN}

Gender merupakan salah satu aspek yang digunakan dalam pemasaran produk. Penggunaan aspek gender itu dalam pemasaran sudah lama ada. Pada katalog Sears pada tahun 1925, misalnya, telah disajikan iklan untuk mainan anak-anak sebagai berikut: "Mothers! Here is a real practical toy for little girls. Every little girl likes to play house, to sweep, and to do mother's work for her". (Sweet, 2014). Akhir-akhir ini, nama brand (Grohmann, 2014; Guevremont dan Grohmann, 2015) bentuk dan warna produk atau kemasan produk merupakan aspek gender yang digunakan dalam pemasaran (Aritonang, 2018; Lieven et al., 2015; Schnurr, 2018; Van Tilburg et al., 2015).

Beberapa hasil penelitian mengenai penggunaan aspek gender dalam pemasaran produk disajikan pada Tabel 1 . Dari 13 penelitian itu hanya 5 penelitian yang mengkaitkan gender dan intensi untuk membeli.

Intensi, keputusan membeli, persepsi atas gender produk, identitas peran jenis kelamin, evaluasi atas produk, kesenangan yang dipersepsi dan self-efficacy, pilihan produk, dan kredibilitas produk sebagai variabel dependen maupun mediasi dan moderator. Sementara itu, jenis kelamin subjek, aspek gender dalam bentuk kemasan dan warna kemasan, norma subjektif, fonts, nama produk, logo, tujuan konsumsi, harapan atas harga, persepsi atas keindahan produk, serta penggunaan jenis garis pada produk digunakan sebagai variabel independen maupun moderator. 
Tabel 1. Ringkasan Penelitian yang Relevan

\begin{tabular}{|c|c|}
\hline Peneliti & Hasil \\
\hline (Aritonang, 2018) & $\begin{array}{l}\text { Intensi membeli pada perempuan lebih kecil daripada laki-laki. } \\
\text { Intensi membeli berdasarkan bentuk kemasan berbeda secara } \\
\text { empiris. } \\
\text { Intensi membeli berdasarkan warna kemasan juga berbeda secara } \\
\text { statistik. } \\
\text { Efek interaksi antara gender, bentuk dan warna kemasan tidak } \\
\text { dapat diuji karena kelemahan dari segi desain penelitian. }\end{array}$ \\
\hline $\begin{array}{l}\text { (Beldad dan Hegner, } \\
\text { 2018) }\end{array}$ & $\begin{array}{l}\text { Kaitan antara norma subjektif dan intensi membeli produk } \\
\text { dimoderasi oleh gender konsumen (Beldad \& Hegner, 2018). }\end{array}$ \\
\hline (Dalgin et al., 2018) & $\begin{array}{l}\text { Di enam negara dari tiga benua menunjukkan bahwa warna } \\
\text { memiliki makna di antara para konsumen ketika membuat } \\
\text { keputusan membeli berbagai produk. } \\
\text { Perempuan lebih senang melihat warna yang ekstrim atau sangat } \\
\text { penting, sementara laki-laki menunjukkan hasil yang berbeda. }\end{array}$ \\
\hline $\begin{array}{l}\text { (Hess dan Melnyk, } \\
\text { 2016) }\end{array}$ & $\begin{array}{l}\text { Isyarat gender yang maskulin (feminin) meningkatkan persepsi } \\
\text { atas kompetensi (warmth) dan intensi membeli brand. } \\
\text { Dengan keberadaan isyarat kompetensi yang rendah, isyarat yang } \\
\text { maskulin (versus feminin) meningkatkan peluang membeli } \\
\text { melalui persepsi atas kompetensi brand. } \\
\text { Keberadaan isyarat kompetensi yang tinggi, isyarat feminin } \\
\text { (versus maskulin) meningkatkan peluang membeli melalui } \\
\text { persepsi atas kehangatan brand. }\end{array}$ \\
\hline (Lieven et al., 2015) & $\begin{array}{l}\text { Logo brand yang heavy (versus slender) dan angular (versus } \\
\text { round) dispersepsi lebih maskulin. } \\
\text { Logo yang slender (versus heavy) dan round (versus angular) } \\
\text { dipsepsi lebih feminin. } \\
\text { Nama brand yang mencakup huruf hidup back (versus front) } \\
\text { dipsersepsi lebih maskulin dan kurang feminin. } \\
\text { Fonts yang blod dan angular (versus slender dan round) } \\
\text { dipsersepsi lebih maskulin (feminin). } \\
\text { Kemaskulinan dan kefeminan brand mempengaruhi secara positif } \\
\text { preferensi atas brand. } \\
\text { Kesesuaian antara gender brand dan gender kategori produk } \\
\text { meningkatkan preferensi atas brand. } \\
\text { Front bold/angular meningkatkan kemaskulinan brand untuk } \\
\text { produk feminin, tapi tidak untuk produk maskulin. } \\
\text { Font yang slender/round meningkatkan kemaskulinan brand } \\
\text { untuk produk yang feminin dan maskulin. } \\
\text { Warna gelap tidak meningkatkan kemaskulinan brand. } \\
\text { Warna cerah meningkatkan kefemininan brand. } \\
\text { Kesesuaian antara gender brand dan jenis kelamin meningkatkan } \\
\text { preferensi atas brand. }\end{array}$ \\
\hline
\end{tabular}


\begin{tabular}{l|l}
\hline (Neale et al., 2015) & Konsumen yang maskulin memiliki tanggapan yang lebih positif
\end{tabular} terhadap brand yang maskulin (versus feminin), sementara tidak ada perbedaan untuk konsumen yang yang feminin dan androgini. Konsumen yang feminin memiliki tanggapan yang lebih positif terhadap brand yang maskulin daripada konsumen yang maskulin pada brand yang feminin.

$\begin{array}{ll}\text { (Schnurr, 2018) } & \text { Ada perbedaan jumlah subjek yang memilih produk berdasakan }\end{array}$ gender bentuk kemasan produk.

Jika konsumsi fungsional diaktifkan, lebih banyak subjek yang memilih produk maskulin daripada feminin.

Jika konsumsi hedonis diaktifkan, lebih banyak subjek yang memilih produk feminin daripada maskulin.

Tidak ada kaitan jenis kelamin subjek dan produk yang dipilih.

Tidak ada efek interaksi tujuan konsumsi dan jenis kelamin subjek terhadap produk yang dipilih.

Gender produk mempengaruhi pilihan produk bergantung pada tujuan konsumsi.

Tidak ada efek utama gender produk maupun penempatan produk terhadap evaluasi produk.

Tidak ada efek interaksi fender produk dan penempatan produk terhadap evaluasi produk.

Tidak ada perbedaan evaluasi atas produk berdasarkan jenis kelamin subjek.

Tidak ada efek interaksi antara jenis kelamin subjek dan warna gender produk maupun penempatan produk terhadap evaluasi atas produk.

Tidak ada efek utama warna gender terhadap evaluasi atas produk.

Tidak ada efek utama penempatan produk terhadap evaluasi atas produk.

Tidak ada efek interaksi warna gender produk dan penempatan produk terhadap evaluasi atas produk.

Ada efek interaksi warna gender produk dan penempatan produk terhadap evaluasi atas produk.

van Tilburg dkk. (2015)

Produk yang proporsinya langsing, berbentuk bulat, atau bergaris lengkung (proporsi besar sekali, berbentuk siku, garis lurus) meningkatkan persepsi atas kefeminian (kemaskulinan) produk. Produk dengan nada yang lebih terang, lebih banyak warna, atau kerefleksian yang berkilau (nada lebih gelap, lebih sedikit warna, kerefleksian yang suram) meningkatkan persepsi atas kefemininan (kemaskulinan) produk.

Sumber: (Diolah, 2019)

Penelitian ini berbeda dari penelitian-penelitian dalam beberapa hal. Satu, intensi membeli masih jarang dikaitkan dengan gender produk. Dua, mungkin belum ada penelitian yang menjelaskan intensi membeli dengan menggunakan empat variabel 
independen pada penelitian ini sekaligus. Variabel independen yang dimaksudkan adalah jenis kelamin, warna produk, bentuk produk dan tujuan konsumsi.

Masalah penelitian ini dirumuskan sebagai berikut: apakah jenis kelamin subjek, gender produk yang terimplementasi pada warna dan bentuk kemasan produk serta tujuan mengkonsumsi berkaitan dengan intensi konsumen untuk membeli produk?

\section{KAJIAN TEORI}

Intensi Membeli Produk dan Jenis Kelamin. Menurut (Pascual et al., 2015), perempuan menikmati proses berbelanja sementara laki-laki hanya berbelanja sebagai manifestasi kebutuhannya. Terkait dengan itu, perempuan menganggap penting pengalaman berbelanja karena merupakan manifesasi dari ruang pribadi dan pemilikan identitas. Namun demikian, akhir-akhir ini, laki-laki mengkonsumsi produk sebagai hal penting sebagai identifikasi dirinya (Shephard et al., 2016).

Terkait dengan itu, ada perbedaan intensi membeli pada perempuan dan laki-laki (Aritonang, 2018; Caro et al., 2017; Chinwong et al., 2018; De Leeuw et al., 2014; (Mouakket, 2018). Pada penelitian (Beldad dan Hegner, 2018) ditemukan bahwa intensi perempuan untuk membeli lebih besar daripada laki-laki. Atas dasar itu hipotesis satu (H1) berikut dapat dirumuskan, yaitu intensi perempuan untuk membeli lebih besar daripada laki-laki.

Intensi Membeli dan Warna Produk. Istilah gender berkaitan dengan aspek psikologis, sedangkan istilah jenis kelamin mengacu pada aspek fisik. Gender brand merupakan sifat kepribadian maskulin dan feminin yang diasosiakan oleh konsumen dengan brand tertentu. Ia membuat pengelompokan lanjut sebagai berikut: brand yang maskulin memiliki sifat maskulin yang tinggi dan kefemininan yang rendah, brand yang feminin memiliki sifat yang kefemininan tinggi dan kemaskulinan yang rendah, brand yang tidak terdiferensiasi memiliki sifat maskulin maupun feminin yang rendah, serta androgin yang memiliki sifat maskulin maupun feminin yang tinggi. Warna memiliki peran yang signifikan dalam pemasaran internasional jika dikaitkan dengan konteks budaya lokal. Manifestasi aspek gender pada produk dapat dalam bentuk, warna maupun garis dan nama pada produk. Aspek gender pada produk yang diteliti adalah warna dan bentuk (kemasan) produk. Warna sudah sering dikaitkan dengan gender. Warna biru, misalnya, sering dikonotasikan pada maskulin. Sebaliknya, warna merah muda dikonotasikan pada gender feminin. Hal itu didasarkan pada pemikiran bahwa penggunaan isyarat gender itu mengaktifkan asosiasi pada gender khusus (Hess dan Melnyk, 2016).

Dari hasil penelitian lainnya dapat diketahui bahwa warna memiliki makna yang berbeda pada konsumen ketika memutuskan untuk membeli produk (Babolhavaeji et al., 2015; Bracke et al., 2019; Budruk dan Feldhaus, 2019; Dalgin et al., 2018; Prado-León et al., 2018). (Aritonang, 2018), (Schnurr, 2018) maupun (Van Tilburg et al., 2015) juga menemukan bahwa prouk berwarna terang cenderung diasosiasikan dengan sifat feminim, sedangkan produk berwarna gelap cenderung diasosiasikan dengan sifat maskulin. Dalam konteks pengembangan situs, warna yang digunakan oleh perempuan dan laki-laki adalah berbeda termasuk jumlah warna yang diinginkan oleh perempuan lebih banyak daripada laki-laki. 
Berdasarkan uraian di atas uraian di atas dapat dirumuskan hipotesis dua $(\mathrm{H} 2)$ bahwa intensi membeli berkaitan dengan warna.

Intensi Membeli dan Bentuk Kemasan. Dari hasil penelitian (Schnurr, 2018) dapat diketahui bahwa para pembeli terutama mendasarkan keputusannya membeli pada penampilan fisik kemasan produk. Dengan pernyataan lain, bentuk kemasan produk berkaitan dengan preferensi konsumen atas produknya. Hasil penelitian (Aritonang, 2018), (Schnurr, 2018) maupun (Van Tilburg et al., 2015) juga menemukan bahwa kemasan berbentuk bulat dan langsing dipersepsikan sebagai feminin. Sebaliknya, kemasan berbentuk bersiku dikonotasikan sebagai maskulin. Hasil penelitian (Nesselhauf et al., 2017) juga menunjukkan bahwa ada perbedaan intensi membeli berdasarkan desain kemasan minuman anggur.

Atas dasar itu dapat dirumuskan hipotesis tiga (H3) bahwa bentuk kemasan berkaitan dengan intensi konsumen untuk membeli produk.

Intensi Membeli Produk, Gender Produk dan Tujuan Konsumsi. Kebanyakan produk memiliki manfaat hedonis dan fungsional. Terkait dengan itu, pemasar dapat menempatkan produknya sebagai memiliki manfaat hedonis dan fungsional. Evaluasi konsumen atas produk dengan ketidaksesuaian bentuk yang moderat lebih disukai daripada produk yang bentuknya sesuai jika produk itu diposisikan sebagai fungsional. Sebaliknya, konsumen menilai produk yang bentuknya sesuai lebih disukai daripada produk dengan ketidaksesuaian bentuk yang moderat jika produknya diposisikan sebagai hedonis. Peran moderasi manfaat produk itu juga teruji pada penelitian yang dilakukan oleh (Shnurr, 2018).

Dari uraian di atas dapat dirumuskan hipotesis empat (H4) bahwa tujuan konsumsi memoderasi kaitan antara intensi membeli dan gender produk.

\section{METODOLOGI}

Desain Penelitian. Desain penelitian ini tergolong penelitian deskriptif, yaitu untuk pengujian hipotesis tanpa ada variabel perlakuan sehingga istilah pengaruh tidak digunakan pada hipoteis penelitian ini. Implikasi disain itu adalah bahwa perlu ukuran sampel yang besar, instrumen pengumpulan data untuk banyak subjek, serta metode kuantatif sebagai alat analisisnya, yang dalam hal ini adalah metode statistik.

Populasi dan Sampel. Populasi penelitian ini adalah mahasiswi/a Fakulas Ekonomi, Universitas Tarumanagara, Jakarta Barat. Ukuran subjek penelitian ini adalah 141 orang. Ukuran ini diperkirakan sesuai dengan alat analisis yang digunakan, yakni analisis variansi.

Instrumen, Reliabilitas dan Validitas. Variabel yang tidak dapat diobservasi secara langsung pada penelitian ini adalah intensi untuk membeli. Intensi itu diukur dengan mengadaptasi instrumen yang telah dikembangkan oleh (Jones et al., 2018) dengan skala Likert yang disesuaikan.

Ada 5 pernyataan untuk mengukur variabel dependen intensi untuk membeli produk. Variabel ini diukur dengan skala Likert yang disesuaikan, dengan skor bergerak dari 1 
sampai dengan 10. Opsi tanggapan yang disediakan adalah Sangat Tidak Setuju sampai dengan Sangat Setuju, yaitu:

- Saya berniat untuk terus membeli produk tersebut.

- Kemungkinan saya akan membeli produk lain yang sejenis,

- Saya berusaha untuk tetap membeli produk tersebut.

- Saya termotivasi untuk membeli produk tersebut.

- Saya termotivasi untuk membeli produk tersebut.

Reliabilitas instrumen penelitian diukur dengan Alpha Cronbach, dan hasilnya disajikan pada Tabel 2 Dari tabel itu dapat diketahui bahwa koefisien reliabilitasnya sama dengan 0,844 dan lebih besar daripada 0,700 sehingga tergolong reliabel (Rust \& Golombok, 1989).

Tabel 2. Statistik Reliabilitas

\begin{tabular}{|c|c|}
\hline Cronbach's Alpha & $\mathrm{N}$ of Items \\
\hline ,844 & 5 \\
\hline
\end{tabular}

Validitas butir instrumen itu dianalisis dengan analisis korelasi butir-total yang telah dikoreksi, dan hasilnya disajikan pada Tabel 3. Dari tabel itu dapat diketahui bahwa koefisien validitasnya bergerak dari 0,554 sampai dengan 0,788, dan lebih besar daripada 0,200 sehingga semua butir pernyataan tergolong.

Tabel 3. Statistik Butir-Total

\begin{tabular}{|c|c|c|c|c|}
\hline & $\begin{array}{c}\text { Scale Mean if } \\
\text { Item Deleted }\end{array}$ & $\begin{array}{c}\text { Scale Variance if } \\
\text { Item Deleted }\end{array}$ & $\begin{array}{c}\text { Corrected Item- } \\
\text { Total } \\
\text { Correlation }\end{array}$ & $\begin{array}{c}\text { Cronbach's } \\
\text { Alpha if Item } \\
\text { Deleted }\end{array}$ \\
\hline int1 & 30,33 & 24,510 &, 554 &, 836 \\
int2 & 29,61 & 23,454 &, 578 &, 831 \\
int3 & 30,31 & 21,216 &, 778 &, 777 \\
int4 & 30,55 & 21,663 &, 716 &, 794 \\
int5 & 30,71 & 21,751 &, 635 &, 817 \\
\hline
\end{tabular}

Sumber: (Hasil pengolahan menggunakan SPSS versi 21, 2019)

Berdasarkan hasil analisis reliabilitas maupun validitas di atas, data yang diperoleh layak digunakan untuk menguji hipotesis penelitian ini. Hasil pengujiannya disajikan pada pasal berikut.

Analisis Data. Semua hipotesis penelitian ini dianalisis dengan Anava dan diuji dengan Uji-F. Perangkat lunak yang digunakan adalah SPSS versi 21. 


\section{HASIL PENELITIAN DAN PEMBAHASAN}

Deskripsi Subjek dan Objek. Statistik deskriptif subjek penelitian ini disajikan pada Tabel 4 sampai dengan Tabel 5. Dari Tabel diketahui bahwa usia subjek antara 17 hingga 22 tahun, dengan rata-rata sebesar 19,67 tahun dan deviasi standar 1,697 tahun.

Tabel 4. Statistik Deskriptif Usia

\begin{tabular}{c|c|c|c|c|c}
\hline & N & Minimum & Maximum & Mean & Std. Deviation \\
\hline USIA & 141 & 17 & 22 & 19,67 & 1,697 \\
Valid N (listwise) & 141 & & & & \\
\hline
\end{tabular}

Sumber: (Hasil pengolahan menggunakan SPSS versi 21, 2019)

Dari Tabel 5 dapat diketahui bahwa 46,1 persen atau 65 orang subjek berjenis kelamin perempuan dan 53,9 persen atau 76 orang berjenis kelamin laki-laki.

Tabel 5. Statistik Deskriptif Jenis Kelamin

\begin{tabular}{cc|c|c|c|c}
\hline & & Frequency & Percent & Valid Percent & Cumulative Percent \\
\hline \multirow{4}{*}{ Valid } & Perempuan & 65 & 46,1 & 46,1 & 46,1 \\
& Laki-laki & 76 & 53,9 & 53,9 & 100,0 \\
& Total & 141 & 100,0 & 100,0 & \\
\hline
\end{tabular}

Sumber: (Hasil pengolahan menggunakan SPSS versi 21, 2019)

Dari Tabel 6 dapat diketahui bahwa skor lima pernyataan mengenai intensi membeli bergerak dari 1 untuk Peranyataan 3 dan 5 sampai dengan 10 untuk semua pernyaaan. Rerata skor lima pernyataan mengenai variabel intensi membeli bergerak dari 7,17 untuk Pernyataan 2 sampai dengan 8,27 untuk Pernyataan 2. Deviasi standar semua pernyataan bergerak dari 1,365 untuk Peranyaan 1 sampai dengan 1,608 untuk Pernyataan 5.

Skor variabel intensi membeli dihasilkan dengan mejumlahkan skor lima pernyataan dan kemudian dibagi dengan 5 pernyataan sehingga diperoleh skor rata-rata. Dari Tabel 6 dapat diketahui bahwa skor intensi membeli bergerak dari 1 sampai dengan 10, dengan sama dengan 7,576 dan deviasi standar sama dengan 1,1639.

Hasil Pengujian Hipotesis. Hasil analisis dan pengujian atas semua hipotesis penelitian ini disajikan pada Tabel 5 sampai dengan Tabel 13. Statistik deskriptif dan hasil pengujian hipotesis satu (H1) bahwa intensi perempuan untuk membeli lebih besar daripada laki-laki teruji secara empiris disajikan pada tabel. 
Tabel 6. Statistik Deskriptif Butir dan Variabel

\begin{tabular}{c|c|c|c|c|c}
\hline & $\mathbf{N}$ & Minimum & Maximum & Mean & Std. Deviation \\
\hline int1 & 141 & 3 & 10 & 7,55 & 1,365 \\
int2 & 141 & 2 & 10 & 8,27 & 1,473 \\
int3 & 141 & 1 & 10 & 7,57 & 1,465 \\
int4 & 141 & 3 & 10 & 7,33 & 1,495 \\
int5 & 141 & 1 & 10 & 7,17 & 1,608 \\
INTENSI & 141 & 2,4 & 10,0 & 7,576 & 1,1639 \\
Valid N (listwise) & 141 & & & & \\
\hline
\end{tabular}

Sumber: (Hasil pengolahan menggunakan SPSS versi 21, 2019)

Tabel 7. Statistik Kelompok Jenis Kelamin

\begin{tabular}{cc|c|c|c|c}
\hline & Jenis Kelamin & $\mathbf{N}$ & Mean & Std. Deviation & Std. Error Mean \\
\hline \multirow{2}{*}{ INTENSI } & Perempuan & 73 & 8,266 &, 8233 &, 0964 \\
& Laki-laki & 68 & 6,835 & 1,0133 &, 1229 \\
\hline
\end{tabular}

Sumber: (Hasil pengolahan menggunakan SPSS versi 21, 2019)

Tabel 8. Hasil uji-t Intensi Berdasarkan Jenis Kelamin

\begin{tabular}{c|c|c|c|c|c|c}
\hline \multirow{2}{*}{$t$} & \multirow{2}{*}{ Df } & $\begin{array}{c}\text { Sig. } \\
\text { (2-tailed) }\end{array}$ & $\begin{array}{c}\text { Mean } \\
\text { Difference }\end{array}$ & $\begin{array}{c}\text { Std. Error } \\
\text { Difference }\end{array}$ & \multicolumn{2}{|c}{$\begin{array}{c}\text { 95\% Confidence Interval } \\
\text { of the Difference }\end{array}$} \\
\cline { 5 - 7 } & & & & & Lower & Upper \\
\hline 9,228 & 139 &, 000 & 1,435 &, 1550 & 1,1240 & 1,7370 \\
\hline
\end{tabular}

Levene's Test for Equality of Variances: $F=0,060 ;$ Sig. $=0,806$

Sumber: (Hasil pengolahan menggunakan SPSS versi 21, 2019)

Dari Tabel 7 dapat diketahui bahwa deviasi standar skor intensi membeli pada perempuan $(0,8233)$ lebih kecil daripada pada laki-laki $(1,0133)$, yang berarti bahwa sebaran skor intensi membeli pada perempuan lebih kecil daripada pada laki-laki.

Secara deskripsif rerata skor intensi membeli untuk perempuan $(8,266)$ lebih besar daripada intensi membeli untuk laki-laki $(6,825)$, yaitu sebesar 1,435. Hal itu sesuai dengan yang dirumuskan pada hipotesis satu (H1).

Secara inferensial, hasil pengujian atas H1 disajikan pada Tabel 8. Dari tabel itu dapat diketahui bahwa asumsi yang melatari uji yang digunakan, yaitu variansi skor intensi membeli pada perempuan dan laki-laki tidak berbeda secara statistik. Hal itu dapat diketahui dari nilai Signifikansi F Levene $(0,806)$ yang lebih besar daripada 0,050. Dengan demikian, uji-t untuk dua kelompok independen layak untuk dilakukan. 
Dengan tingkat keyakinan sebesar 95\%, rata-rata perbedaan intensi membeli antara perempuan dan laki-laki pada populasinya diperkirakan bergerak dari 1,1240 sampai dengan 1,7370 .

Nilai t yang dihasilkan pada pengujian perbedaan rata-rata intensi membeli antara perempuan dan laki-laki sama dengan 9,228 dan nilai signifikansi t-nya sama dengan 0,000. Itu berarti bahwa secara statistik rata-rata skor intensi perempuan untuk membeli lebih besar daripada rata-rata skor intensi laki-laki. Dengan demikian, H1 bahwa intensi perempuan untuk membeli lebih besar daripada laki-laki teruji secara empiris.

Statistik deskriptif dan hasil pengujian hipotesis dua (H2) bahwa intensi membeli berkaitan dengan warna teruji secara empiris disajikan pada Tabel 9.

Tabel 9. Statistik Kelompok Warna Kemasan

\begin{tabular}{l|l|r|r|r|r}
\hline & Warna Kemasan & N & Mean & \multicolumn{1}{c|}{$\begin{array}{c}\text { Std. } \\
\text { Deviation }\end{array}$} & $\begin{array}{c}\text { Std. Error } \\
\text { Mean }\end{array}$ \\
\hline \multirow{2}{*}{ INTENSI } & Cerah (merah muda): feminin & 66 & 8,318 &, 8693 &, 1070 \\
\cline { 2 - 6 } & Gelap (biru tua): maskulin & 75 & 6,923 &, 9874 &, 1140 \\
\hline
\end{tabular}

Sumber: (Hasil pengolahan menggunakan SPSS versi 21, 2019)

Tabel 10. Hasil uji-t Intensi Berdasarkan Warna Kemasan

\begin{tabular}{c|c|c|c|c|c|c}
\hline \multirow{t}{*}{} & df & $\begin{array}{c}\text { Sig. } \\
\text { (2-tailed) }\end{array}$ & $\begin{array}{c}\text { Mean } \\
\text { Difference }\end{array}$ & $\begin{array}{c}\text { Std. Error } \\
\text { Difference }\end{array}$ & $\begin{array}{c}\text { 95\% Confidence Interval } \\
\text { Of the Difference }\end{array}$ \\
\cline { 4 - 6 } & & & & & Lower & Upper \\
\hline 8,852 & 139 &, 000 & 1,3955 &, 1576 & 1,0838 & 1,7072 \\
\hline \multicolumn{6}{l}{ Levene's Test for Equality of Variances: $\mathrm{F}=0,345 ;$ Sig. $=0,558$} \\
\hline
\end{tabular}

Sumber: (Hasil pengolahan menggunakan SPSS versi 21, 2019)

Dari Tabel 9 dapat diketahui bahwa rata-rata intensi membeli produk yang memiliki kemasan berwarna feminin (merah muda), yakni 8,318, lebih besar daripada rata-rata intensi membeli produk yang memiliki kemasan berwarna maskulin (biru tua), yakni 6,923, dengan selisih sebesar 1,3955. Jadi, statistik deskriptif dapat diketahui bahwa intensi membeli produk dengan kemasan berwarna feminin lebih besar daripada intensi membeli produk dengan kemasan berwarna maskulin.

Deviasi standar skor intensi membeli produk dengan kemasan berwarna feminin $(0,8693)$ lebih kecil daripada deviasi standar skor intensi membeli produk dengan kemasan berwarna maskulin $(0,9874)$. Itu berarti skor intensi membeli produk yang memiliki kemasan berwarna maskulin lebih menyebar daripada skor intensi membeli produk yang memiliki kemasan berwrana feminin.

Asumsi yang melatari penggunaan uji-t pada dua kelompok independen adalah bahwa variansi skor variabel dependen pada kedua kelompok itu adalah homogen. Sebagaimana nilai signifikansi $F$ Levene $(0,558)$ yang lebih besar daripada 0,050 maka 
asumsi itu terpenuhi. Dengan demikian uji-t untuk dua kelompok independen layak untuk digunakan, dan hasilnya disajikan pada Tabel 10.

Nili t yang diperoleh sama dengan 8,852 dengan signifikansi sebesar 0,000. Itu berarti bahwa secara statistik ada perbedaan intensi membeli berdasarkan warna kemasan produk. Dalam hal ini, intensi membeli produk yang memiliki kemasan berwarna feminin lebih besar daripada intensi membeli produk yang memiliki kemasan berwarna maskulin. Dengan demikian, konsiten juga dengan statistik deskriptif yang telah diuraikan, hipotesis dua $(\mathrm{H} 2)$ bahwa intensi membeli berkaitan dengan warna teruji secara empiris.

Dengan tingkat keyakinan sebesar 95\%, rerata perbedaan intensi membeli produk berdasarkan warna kemasan pada populasinya diperkirakan bergerak dari 1,0838 sampai dengan 1,7072 .

Statistik deskriptif dan hasil pengujian hipotesis tiga (H3) bahwa bentuk kemasan berkaitan dengan intensi konsumen untuk membeli produk disajikan pada Tabel 11 dan Tabel 12.

Dari Tabel 11 dan Tabel 12 dapat diketahui bahwa deviasi standar rerata skor intensi membeli produk yang berbentuk feminin (bulat, lonjong) $(0,7190)$ lebih kecil daripada deviasi standar rerata skor intensi membeli produk yang berbentuk maskulin (persegi, kotak) (0,9601), dengan selisih sebesar 1,6092. Itu berarti bahwa skor rerata intensi membeli produk berbentuk maskulin lebih menyebar daripada skor rerata intensi membeli produk berbentuk feminin.

Tabel 11. Statistik Kelompok Bentuk Kemasan

\begin{tabular}{l|l|c|c|c|c}
\hline & \multicolumn{1}{|c|}{ Bentuk Kemasan } & N & Mean & $\begin{array}{c}\text { Std. } \\
\text { Deviation }\end{array}$ & $\begin{array}{c}\text { Std. Error } \\
\text { Mean }\end{array}$ \\
\hline \multirow{2}{*}{ INTENSI } & Bulat (lonjong): feminin & 74 & 8,341 &, 7190 &, 0836 \\
\cline { 2 - 6 } & Persegi (kotak): maskulin & 67 & 6,731 &, 9601 &, 1173 \\
\hline
\end{tabular}

Sumber: (Hasil pengolahan menggunakan SPSS versi 21, 2019)

Tabel 12. Hasil uji-t Intensi Berdasarkan Bentuk Kemasan

\begin{tabular}{c|c|c|c|c|c|c}
\hline \multirow{2}{*}{$\mathbf{t}$} & \multirow{2}{*}{ df } & $\begin{array}{c}\text { Sig. } \\
\text { (2-tailed) }\end{array}$ & \multirow{2}{*}{$\begin{array}{c}\text { Mean } \\
\text { Difference }\end{array}$} & \multirow{2}{*}{$\begin{array}{c}\text { Std. Error } \\
\text { Difference }\end{array}$} & \multicolumn{2}{|c|}{$\begin{array}{c}\text { 95\% Confidence Interval } \\
\text { of the Difference }\end{array}$} \\
\cline { 5 - 7 } & & & & & Lower & Upper \\
\hline 11,331 & 139 &, 000 & 1,6092 &, 1420 & 1,3284 & 1,8900 \\
\hline
\end{tabular}

Levene's Test for Equality of Variances: $F=0,000 ;$ Sig. $=0,988$

Sumber: (Hasil pengolahan menggunakan SPSS versi 21, 2019)

Secara deskriptif, rerata skor intensi membeli produk berbentuk feminin $(8,341)$ lebih besar daripada rerata skor intensi membeli produk berbentuk maskulin $(6,731)$, dengan selisih sebesar 1,6092. Ini sesuai dengan yang dirumuskan pada H3.

Untuk menguji secara inferensial $\mathrm{H} 3$, asumsi bahwa variansi skor intensi membeli untuk produk berbentuk feminin dan maskulin harus homogen. Hasil pengujian asumsi ini disajikan pada Tabel 12, yakni signifikansi nilai $\mathrm{F}$ Levene sebesar 0,988 yang lebih besar 
daripada 0,050. Itu berarti bahwa asumsi homogenitas vaiansi itu teruji secara statistik. Dengan demikian, penggunaan uji-t untuk dua kelompok independen layak dilakukan.

Hasil uji-t atas rerara skor intensi membeli berdasarkan bentuk produk disajikan pada Tabel 12. Signifikansi nilai t yang dihasilkan sama dengan 0,000 dan lebih kecil daripada 0,05 sehingga secara statistik ada perbedaan rerata skor intensi membeli untuk produk berbentuk feminin dan maskulin. Dalam hal ini, rerata skor intensi membeli untuk produk berbentuk feminin lebih besar daripada rerata skor intensi membeli produk berbentuk maskulin, yaitu sebesar 1,6092. Dengan demikian, H3 bahwa bentuk kemasan berkaitan dengan intensi konsumen untuk membeli produk teruji secara statistik.

Hasil pengujian hipotesis empat (H4) bahwa tujuan konsumsi memoderasi kaitan antara intensi membeli dan gender produk.disajikan pada Tabel 13.

Tabel 13. Hasil Pengujian Efek-efek antarsubjek

\begin{tabular}{|c|c|c|c|c|c|}
\hline \multicolumn{6}{|c|}{ Dependent Variable: INTENSI } \\
\hline Source & $\begin{array}{l}\text { Type III Sum } \\
\text { of Squares }\end{array}$ & df & Mean Square & $\mathbf{F}$ & Sig. \\
\hline Corrected Model & $125,515^{\mathrm{a}}$ & 7 & 17,931 & 37,191 & 000 \\
\hline Intercept & 5326,493 & 1 & 5326,493 & 11047,928 & ,000 \\
\hline MANFAAT & 2,618 & 1 & 2,618 & 5,430 & ,021 \\
\hline BENTUK & 31,528 & 1 & 31,528 & 65,394 & 000 \\
\hline WARNA & 14,862 & 1 & 14,862 & 30,825 &, 000 \\
\hline MANFAAT $*$ BENTUK &, 061 & 1 &, 061 &, 126 &, 723 \\
\hline MANFAAT $*$ WARNA & ,047 & 1 & ,047 & ,098 & ,755 \\
\hline BENTUK * WARNA & ,349 & 1 & ,349 & ,724 & ,396 \\
\hline $\begin{array}{l}\text { MANFAAT } * \text { BENTUK } \\
* \text { WARNA }\end{array}$ & 654 & 1 & ,654 & 1,356 & ,246 \\
\hline Error & 64,123 & 133 & ,482 & & \\
\hline Total & 8282,200 & 141 & & & \\
\hline Corrected Total & 189,638 & 140 & & & \\
\hline
\end{tabular}

a. R Squared $=, 662$ (Adjusted R Squared $=, 644$ )

Sumber: (Hasil pengolahan menggunakan SPSS versi 21, 2019)

Dimensi gender yang digunakan pada penelitian ini terdiri atas warna kemasan dan bentuk produk, yang masing-masing terdiri atas feminin dan maskulin. Terkait dengan itu, untuk menguji $\mathrm{H} 4$ digunakan tiga variabel independen, yaitu jenis warna, bentuk kemasan, dan tujuan (manfaat) produk. Variabel dependennya adalah intensi membeli produk.

Dari Tabel 13 dapat diketahui tiga efek utama yang diuji. Satu, efek utama Manfaat (Tujuan) konsumsi terhadap intensi membeli produk dengan nilai $\mathrm{F}$ sebesar 5,430 dan signifikansi $\mathrm{F}$ sebesar 0,021. Itu berarti bahwa secara statistik ada perbedaan intensi membeli berdasarkan tujuan konsumsi. Rerata intensi membeli untuk manfaat yang hedonis sebesar 8,115 dan untuk yang fungsional sebesar 6,908, atau berbeda sebesar 1,207 .

Dua, efek utama Bentuk terhadap intensi membeli produk dengan nilai dengan nilai F sebesar 65,394 dan signifikansi F sebesar 0,000. Ini konsisten dengan hasil pengujian 
H3 bahwa ada perbedaan intensi membeli beredasarkan bentuk produk, yang berarti bahwa secara statistik ada perbedaan intensi membeli berdasarkan bentuk produk.

Terakhir, efek utama Warna terhadap intensi membeli produk dengan nilai F sebesar 30,825 dan signifikansi $\mathrm{F}$ sebesar 0,000. H2 bahwa ada perbedaan intensi membeli berdasarkan warna, yang berarti bahwa secara statistik ada perbedan intensi membeli berdasarkan warna produk.

Berdasarkan 3 efek utama di atas, ada empat efek interaksi yang dapat diuji. Satu, efek interaksi antara Tujuan (Manfaat) konsumsi dan Bentuk terhadap intensi membeli produk, dengan nilai $\mathrm{F}$ sebesar 0,126 dan signifikansi $\mathrm{F}$ sebesar 0,723 . Itu berarti bahwa secara statistik tidak ada efek interaksi antara tujuan dan bentuk produk terhadap intensi membeli produk.

Dua, efek interaksi antara Manfaat dan Warna terhadap intensi membeli produk, dengan nilai $F$ sebesar 0,098 dan signifikansi $F$ sebesar 0,775. Ini berarti bahwa tidak ada efek interaksi antara manfaat konsumsi dan warna produk terhadap intensi membeli produk.

Tiga, efek interaksi antara Bentuk dan Warna terhadap intensi membeli produk, dengan nilai $F$ sebesar 0,724 dan signifikansi $F$ sebesar 0,396. Ini berarti bahwa secara statistik tidak ada efek interaksi antara bentuk dan warna produk terhadap intensi membeli produk.

Empat, efek interaksi Bentuk, Warna, dan Tujuan konsumsi terhadap intensi membeli produk, dengan nilai F sebesar 1,356 dan signifikansi F sebesar 0,246. Ini berarti bahwa secara statistik tidak ada efek interaksi antara bentuk, warna dan tujuan konsumsi terhadap intensi membeli produk.

Dari empat hasil pengujian efek interaksi di atas, tidak ada satu pun yang teruji secara statistik. Secara khusus, yakni yang berkaitan dengan H4, baik efek interaksi antara manfaat dan warna maupun efek interaksi antara manfaat dan bentuk produk tidak teruji secara statistik. Demikian juga dengan efek interaksi manfaat, warna dan bentuk terhadap intensi membeli produk tidak teruji secara statistik. Dengan demikian, H4 bahwa manfaat konsumsi tidak memoderasi kaitan antara warna dan intensi membeli maupun kaitan antara bentuk dan intensi membeli.

\section{PEMBAHASAN}

Pada Teori Perilaku Terencana dinyatakan bahwa intensi merupakan variabel yang paling dekat untuk menjelaskan perilaku. Teori itu telah teruji secara luas dalam berbagai disiplin ilmu, termasuk dalam perilaku konsumen. Kontribusi utama penelitian ini dalam konteks intensi konsumen itu adalah pada penggunaan jenis kelamin, gender produk berupa warna maupun bentuk produk, dan tujuan konsumsi untuk menjelaskan intensi konsumen untuk membeli produk. Terkait dengan itu, ada empat hipotesis megnenai intensi konsumen untuk membeli suatu produk yang digunakan pada penelitian ini. Tiga hipotesis, yaitu hipotesis satu sampai dengan hipotesis tiga, teruji secara empiris dan satu hipotesis, yaitu hipotesis empat, tidak teruji secara empiris.

Dalam hal intensi membeli produk, perempuan lebih memperlakukannya sebagai suatu kenikmatan dan pengalaman yang penting karena merupakan manifestasi ruang pribadi dan identitasnya. Dalam penelitian ini teruji secara empiris bahwa perempuan memiliki intensi membeli yang lebih besar jika dibandingkan dengan laki-laki, 
sebagaimana juga ditemukan pada penelitian yang dilakukan oleh (Beldad dan Hegner, 2018).

Gender tidak berkaitan secara langsung dengan fisik antara laki-laki dan perempuan tapi lebih pada aspek psikologisnya. Aspek psikologis itu dapat berkaitan dengan ciri suatu produk, seperti warna kemasan atau produk. Terkait dengan itu, warna kemasan produk merupakan alat pemasaran yang penting. Hal itu dapat diasosiasikan dengan kebudayaan dan reaksi emosional, yang selanjutnya diasosiasikan dengan gender khusus (Hess dan Melnyk, 2016) maupun produk. Warna dapat digunakan untuk membedakan intensi antara perempuan dan laki-laki untuk membeli suatu produk, sebagaimana teruji secara empiris pada penelitian ini. Dalam hal ini, perempuan memiliki intensi yang lebih besar untuk membeli produk dengan kemasan berwarna cerah dan laki-laki memiliki intensi yang lebih besar untuk membeli produk dengan kemasan yang gelap, sebagaimana juga telah teruji pada beberapa penelitian lainnya (Aritonang, 2018; Schnurr, 2018; Van Tilburg et al., 2015).

Selain pada warna, gender juga termanifestasi pada penampilan fisi atau bentuk produk, yakni mengenai preferensi terhadap bentuk produk. Perempuan memiliki intensi yang lebih besar untuk membeli produk yang berbentuk lonjong sementara laki-laki memiliki intensi yang lebih besar untuk membeli produk yang berbentuk persegi. Hal itu teruji secara empiris pada penelitian ini dan beberapa penelitian lainnya (Aritonang, 2018; Schnurr, 2018; Van Tilburg et al., 2015; Nesselhauf et al., 2017).

Efek interaksi antara manfaat konsumsi dan gender produk terhadap intensi membeli produk. Dalam hal ini, manfaat konsumsi terdiri atas hedonis dan fungsional, gender produk terdiri atas bentuk kemasan [feminin (lonjong) dan maskulin (bersegi)] dan warna kemasan [feminin (cerah) dan maskulin (gelap)]. Hal itu mungkin terjadi karena produk yang digunakan pada penelitian ini hanya satu jenis, yakni shampo. Produk ini kurang dapat dikaitkan dengan manfaat konsumsi, yakni hedonis dan fungsional. Manfaat hedonis seringkali terkait dengan harga yang lebih mahal sedangkan manfaat fungsional seringkali terkait dengan fungsi produk dan bukan harganya. Hal itu sesuai dengan hasil dari beberapa penelitian bahwa produk dapat dikategorikan dari segi ciri hedonis versus manfaatnya. Konsumsi yang bersifat hedonis secara khas termotivasi oleh keinginan daripada kebutuhan sebagaimana pada konsumsi yang termotivasi oleh manfaat yang seringkali mencakup produk yang bersifat praktis atau kebutuhan (Chen et al., 2017). (Nenkov dan Scott, 2014) juga berpendapat bahwa produk hedonis terkait dengan kesenangan sensoris sementara produk yang berorientasi pada manfaat secara khas dibeli untuk tujuan instrumental.

Konsumsi berdasarkan manfaat didukung oleh norma sosial dengan mana orang mestinya lebih berfokus pada kebutuhan dasar dan membelanjakan lebih banyak sumberdaya pada kebutuhan agar dapat bertahand alam jangka panjang. Namun demikian, mungkin belum ada penelitian mengenai kategorisasi produk yang tergolong hedonis dan manfaat.

\section{KESIMPULAN}

Berdasarkan diskusi pada bab sebelumnya, ada empat kesimpulan penelitian ini. Satu, intensi perempuan untuk membeli lebih besar daripada intensi laki-laki untuk membeli. Dua, intensi untuk membeli produk yang berwarna feminim (merah muda) lebih 
besar daripada intensi membeli produk berwarna maskulin (biru tua). Tiga, intensi membeli produk berbentuk feminin (lonjong) lebih besar daripada intensi membeli produk berbentuk maskulin (kotak). Empat, efek moderasi tujuan konsumsi (hedonis versus fungsional) pada kaitan antara intensi membeli dan gender produk tidak teruji secara empiris.

Keterbatasan dan Saran. Ada beberapa keterbatasan pada penelitian ini. Satu, pada penelitian ini tidak dibandingkan secara rinci hal yang mendorong perbedaan intensi membeli antara perempuan dan laki-laki, misalnya dari segi kenikmatan, kebutuhan, dan identitas diri. Pada penelitian yang akan datang, rincian itu perlu dilakukan melalui penelitian kualitatif. Dengan demikian, latar yang membedakan intensi antara perempuan dan laki-laki untuk membeli menjadi dapat diketahui.

Dua, pada penelitian ini tidak digunakan produk yang lebih spesifik untuk perempuan maupu laki-laki sehingga tidak dapat diidentifikasi secara eksplisit kaitan antara spesifikasi produk berdasarkan jenis kelamin itu dan intensi membeli. Untuk penelitian yang akan datang perlu digunakan produk yang lebih spesifik untuk perempuan dan laki-laki maupun yang tidak spesifik sehingga dapat diketahui kontribusi spesifikasi produk berdasarkan jenis kelamin itu pada intensi untuk membeli produk.

Dengan mempertimbangkan dua saran untuk penelitian di atas, efek moderasi tujuan konsumsi pada kaitan antara intensi membeli dan gender produk diharapkan dapat dilakukan sehingga efeknya dapat teruji secara empiris.

\section{DAFTAR PUSTAKA}

Aritonang R., Lerbin R. (2018). Intensi membeli, gender, warna dan bentuk kemasan produk. Research report. Jakarta: LPPI Tarumanagara University.

Babolhavaeji, M., Vakilian, M. A. and Slambolchi, A. (2015). Color Preferences Based on Gender As a New Approach in Marketing. Andanced Social Humanities and Management, 2 (1), 35-44.

Beldad, A. and Hegner, S. (2018). Determinants of Fair Trade Product Purchase Intention of Dutch Consumers According To The Extended Theory of Planned Behaviour The Moderating Role of Gender. Journal of Consumer Policy, 41, 191-210.

Bracke, M. B. M., Koene, P., Estevez, I., Butterworth, A., and de Jong, I. C. (2019). Broiler Welfare Trade-Off: A Semi-Quantitative Welfare Assessment For Optimised Welfare Improvement Based On An Expert Survey. PLos One, 14 (10), 1-24.

Budruk, M., and Feldhaus, A. (2019). Understanding Place Meaning Through Integrative Research: Perspectives From The Natural Resource Social Sciences and The Humanities. Journal of Leisure Research, 50_5), 461-478.

Caro-González, F.-J., Romero-Benabent, H. and Torné, I. S. (2017). The Influence of Gender on The Entrepreneurial Intentions of Journalism Students. Intangible Capital, 13 (2), 430-478.

Chen, C. Y., Lee, L., and Yap, A. J. (2017). Control Deprivation Motivates Acquisition of Utilitarian Products. Journal of Consumer Research, 43, 1031-1047.

Chinwong, D., Mookmanee, N., Chongpornchai, J., and Chinwong, S. (2018). A comparison of gender differences in smoking behaviors, intention to quit, and 
micotine dependence among Thai University Students. Journal of Addiction, 2018, 1-8.

Dalgin, H. M.; Sraihenn, A. and Okcay, O. (2018). Gender Differences in Product Color Importance, Color Choice, and Meaning Of Color: A cross-country study. Journal of Business and Behavioral Sciences, 30 (1), 88-99.

De Leeuw, A.; Valois, P.; Morin, J.A.S. and Schmidt, P. (2014). Gender Differences in Psychosocial Determinants of University Students' Intentions To Buy Fair Trade Products. Journal of Consumer Policy, 37, 485-505.

Hess, A.C. and Melnyk, V. (2016). Pink or Blue? The Impact of Gender Cues on Brand Perceptions. European Journal of Marketing, 50 (9/10), 1550-1574.

Jones, C. L. E., Barney, C. and Farmer, A. (2018). Appreciating Anonymity: An Exploration of Embarrassing Products and the Power of Blending. Journal of Retailing, 94 (2) 186-202.

Lieven, T., Grohmann, B., Herrmann, A., Landwehr, J.R., van Tilburg, M., Lee, N. and Biswas, D. (2015). The Effect of Brand Design on Brand Gender Perceptions and Brand Preference. European Journal of Marketing, 49 (1/2)), 146-169.

Mouakket, S. (2018). The Role of Personality Traits in Motivating Users' Continuance Intention Towards Facebook: Gender Differences. The Journal of High Technology Management Research, 29 (1), 124-140.

Neale, L., Robbie, R. and Martin, B. (2015). Gender Identity and Brand Incongruence: When in Doubt, Pursue Masculinity. Journal of StrategicMarketing, 24 (5), 1-13.

Nenkov, G. Y., and Scott, M. L. (2014). "So cute I could eat it up": Priming Effects of Cute Products on Indulgent Consumption. Journal of Consumer Research, 41, 326341.

Nesselhauf, L.; Deker, J. S. and Fleuchaus, R. (2017). Information and Involvement: The Influence on The Acceptance of Innovative Wine Packaging. International Journal of Wine Business Research, 29 (3), 285-298.

Pascual-Miguel, F.J., Agudo-Peregrina, Á.F. and Chaparro-Peláez, J. (2015). Influences of Gender and Product Type on Online Purchasing. Journal of Business Research, 68, $1550-1556$.

Prado-León, L. R., Zambrano-Parado, P. L., Herrada-Rodríguez, S. and Felizardo-Gómez, S. (2018). Color Preferences For Private and Semi-Private Areas in Hotels. Universal Journal of Psychology 6 (4), 113-120.

Schnurr, Benedikt. (2018). What's Best for whom? The Effect of Product Gender Depends on Positioning. European Journal of Marketing, 52 (1/2), 367-391.

Shephard, A., Pookulangara, S., Kinley, T.R. and Josiam, B.M. (2016). Media Influence, Fashion, and Shopping: A Gender Perspective. Journal of Fashion Marketing and Management: An International Journal, 20(1), 4-18.

Sweet, E. (2014). "Toys Are More Divided By Gender Now Than They Were 50 Years Ago," The Atlantic, 09-Dec-2014. [Online]. Available: http://www.theatlantic.com/business/archive/2014/12/toys-are-more-divided-bygender-now-than-they-were-50-years-ago/383556/. [Accessed: 14-Sep-2016].

Van Tilburg, M., Lieven, T., Herrmann, A. and Townsend, C. (2015). Beyond 'Pink it and Shrink it' Perceived Product Gender, Aesthetics, and Product Evaluation. Psychology \& Marketing, 32 (4), 422-437. 